\title{
CO BUDEME DĚLAT ZÍTRA? POKUSÍME SE PŘEŽÍT! VZDĚLÁVÁNÍ DOMA V DOBĚ KORONAVIROVÉ PANDEMIE Z PERSPEKTIVY MATEK
}

\author{
WHAT ARE WE GOING TO DO TOMORROW? \\ TRY TO SURVIVE! EDUCATION AT HOME \\ DURING A CORONAVIRUS PANDEMIC \\ FROM THE PERSPECTIVE OF MOTHERS
}

\author{
DANIELA ŠIMKOVÁ
}

\begin{abstract}
Abstrakt
Rok 2020 vystibuji dvě slova - koronavirová pandemie. Bezprecedentni pandemická událost zasábla všechny oblasti společenskébo života, vąěláváni nebylo výjimkou. Pro zajištèni kontinuity výuky prisstoupily školy k distančnimu vądéláváni. Přestože za va děláváni nesly blavni zodpovědnost školy, zejména u dètí na primárním stupni mèli rodiče v procesu učeni kličcovou roli. Cílem studie bylo zjistit, jake běbem pandemie covid-19 matky prvostupnových dětí pristupovaly ke vąèlávání doma. Kvalitativně orientované výzkumné šetreni vycházi z dvanácti bloubkových polostrukturovaných roz̧ovori. Analýza dat vedla k vytvoreni pèti

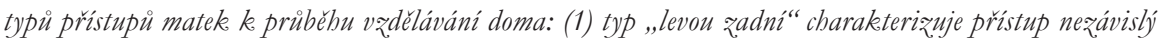
na škole a výrazně angažovaný ve vądéláváni doma; (2) typ "plnime nad plán" vystibuje prístup striktně organizovaný; (3) typ „dre to, ale jde to" charakterizuje př́stup matek, které znaly svoje limity, a nenechaly se vzdèláváním doma pobltit; (4) typ „držime se zuby nebty“popisuje prìstup matek, které se pres své vyčerpani snažily, aby jejich dèti splnily všechny školnípovinnosti; a (5) typ „tonoucí se stébla chytá" zastupuje rezignovaný prìstup matky, keterá by potrébovala pro zuládáni vadèláváni doma vètši podporu ze strany školy i rodiny.
\end{abstract}

\section{Klíčová slova}

pandemie covid-19, vždèláváni doma, distanční vądèláváni, genderové nerovnosti, dopad pandemie covid-19 na rodiny

\section{Abstract}

The year 2020 can be described in two words: coronavirus pandemic. The unprecedented pandemic event affected all areas of social life, and education was no exception. To ensure the continuity of teaching, schools began distance education. Although education was mainly the responsibility of schools, parents played a key 
role in the learning process, especially among children at the primary level. The aim of the study was to investigate how mothers of primary-level pupils approached education at home during the COVID-19 pandemic. The qualitatively oriented research investigation is based on $12 \mathrm{in}$-depth semi-structured interviews. Data analysis led to the creation of five types of approaches to education at home. The "easy peasy" type characterizes an approach independent of school and heavily involved in education at home. The "we're on top of the plan" type captures a strictly organized approach. The "it's work, but it works" type characterizes the approach of mothers who knew their limits and did not let education at home consume them. The "fight tooth and nail" type describes the approach of mothers who, despite their exhaustion, tried to get their children to perform all their school duties. The "clutching at straws" type represents the resigned approach of the mother who needs more support from the school and family to manage education at home.

\section{Keywords}

pandemic COVID-19, education at home, distance education, gender inequalities, COVID-19 impact on families

\section{Úvod}

Dne 11. 3. 2020 prohlásila Světová zdravotnická organizace šírení koronaviru za pandemii (World Health Organization [WHO], 2020). V dnešní době nejsou dle UNESCO (2020) zejména vyspělé státy zvyklé zdravotní krize zažívat. Ačkoliv děti nepatřily ze zdravotního hlediska mezi nejohroženější skupinu, Spojené národy (United Nations, 2020) varovaly, že kvalitu jejich životů zásadně ovlivňovaly socioekonomické dopady na jejich rodiny.

Jednotlivé státy se snažily bránit šíření pandemie a zmírňovat její dopady různě přísnými restrikcemi. $V$ rámci restrikcí se většina států rozhodla k uzavření vzdělávacích institucí. UNESCO (2021) dokládá, že mezi 11. březnem 2020 a 2. únorem 2021 byly školy celkově uzavřené průměrně 95 dní.

Vzdělávací instituce se snažily minimalizovat potenciální ztráty v rozvoji učení přesunutím výuky do online prostoru. Postupem času většina vlád zemí EU přijala opatření umožňující školám zavedení distančního vzdělávání s podporou digitálních technologií a prostřednictvím dalších médií (Carretero et al., 2021). Takto realizovanou výuku označují dokumenty EU jako „remote education“ (Di Pietro et al., 2020), popr.. „blended education“ (Carretero et al., 2021).

V kontextu České republiky se ustálilo užívání termínu distanční vzdělávání (MŠMT, 2020). Na základě zkušeností z druhého pololetí školního roku 2019/2020 byla ve školském zákoně 561/2004 Sb. vyhláškou č. 349/2020 Sb. legislativně ukotvena pravidla pro vzdělávání distančním způsobem v mimořádných prrípadech uzavření škol nebo zákazu prrítomností žáků ve školách.

Přestože bylo smyslem zavedení distančního vzdělávání zajištění kontinuity výuky, Lucas et al. (2020) upozorňují, že se školy soustředily na ty části kurikula, které vyhodnotily za lépe zvládnutelné v domácím prostředí. Náročnost distanční výuky a její nižší efektivita vedla ze strany MŠMT k dopo- 
ručení redukovat vzdělávací obsahy se zaměřením na základní znalosti a dovednosti a jejich důkladné procvičování. Nejméně bylo redukováno učivo ve stěžejních předmětech jako jsou matematika, čeština a cizí jazyk (Pavlas et al., 2021).

V průběhu distančního vzdělávání se museli, jak konstatuje Di Pietro et al. (2020), žáci potýkat se změnami ve způsobech interakce a se snižující se motivací. I tak někteří rodiče kvitovali distanční výuku jako něco, co dětem dodává v nejistých časech disciplínu a řád (Nani \& Sibanda, 2020).

Distanční vzdělávání zároveň více rozevřelo nůžky existujících nerovností ve vzdělávání. Di Pietro et al. (2020) připomínají vztah mezi průběhem distančního vzdělávání a podporou ze strany rodiny. Poukazují, že děti podporované svými rodiči věnovaným časem nebo znalostmi dosahovaly lepších výsledků, což může vést $\mathrm{k}$ rozdílům $\mathrm{v}$ učebním pokroku vzhledem k vrstevníkům bez souvislé rodičovské podpory. Nevýhody distančního vzdělávání více dopadaly na zranitelnější, a to nejen na děti pocházející z méně podnětného či ohrožujícího prostředí, ale zasáhly i děti se speciálními vzdělávacími potřebami, se zdravotním postižením, děti single rodičů i rodiny s více dětmi. Podle organizace Člověk v tísni (2021) distanční výuka, tak jak byla realizovaná v České republice, zvýhodňovala děti z lépe zabezpečených a vzdělanějších rodin.

Uzavření vzdělávacích institucí a zavedení distančního vzdělávání přinesla nebývalý jev: vzdělávací monopol škol se částečně přesunul do rodin dětí. Frombergerová (2020, s. 221) uvádí, že se rodina „najednou snaží přebírat úlohy, které si do ted’ nárokovalo jen školstvi“". Rodiče se stali zásadním prvkem $\mathrm{v}$ kontinuitě vzdělávání svých dětí, podporou, aby distanční výuka probíhala úspěšně. Právě proto se pozornost výzkumného šetření soustředí na vzdělávání doma probíhající v prostředí rodin (zejména z perspektivy žen-matek).

\section{Vzdělávání doma v době pandemické}

Rodiče se během distančního vzdělávání ocitli ze dne na den v rolích motivátorů, facilitátorů učení a asistentů učitelů (Carretero et al., 2021). Dle MŠMT (2020) měli vytvořit adekvátní prostředí pro učení a ověřovat, zda dítě zadané práci rozumí. Zdůrazňuji, že jejich úkolem nebylo „přebírat povinnosti školy a vzdělávat své dítě v domácích podmínkách“ (MŠMT, 2020, s. 12).

Zejména děti na primárním stupni vzdělávání potřebovaly ze strany rodičů větší podporu. Di Pietro et al. (2020) připomínají, že se obecné výhody distančního vzdělávání netýkají dětí v primárním vzdělávání. Prvostupňové děti nejsou samostatné $\mathrm{v}$ organizaci učiva, chybí jim vnitřní motivace, neovládají time management. 
Rodiče své děti podporovali různými způsoby. Poskytovali jim technickou pomoc při realizaci online výuky. Přenesení výuky do tohoto prostředí se stalo pro některé rodiny výzvou: ve smyslu digitální vybavenosti domácnosti, komplikací v podobě slabého internetového připojení, vysokých cen dat či vlastních digitálních kompetencí rodičů (Nani \& Sibanda, 2020).

Termín pro vzdělávání probíhající $\mathrm{v}$ době distanční výuky přímo $\mathrm{v}$ domácnostech vymezuji Švaříček et al. (2020, s. 10): „Pro vzdělávánív domácím prostř̌edí po uzavření škol v rámci karantény používáme označení ,vzdělávání doma“ / ,výuka doma nebo ,vzdělávání v domácím prostředí / ,výuka v domácím prostředíc“" V rámci tohoto výzkumného šetření nadále pracuji s termínem „vzdělávání doma“.

Rodiče pomáhali během vzdělávání doma dětem s vysvětlováním látky a vypracováváním školou zadané práce. Mnozí se ocitli v roli učitelů svých dětí. Často poukazovali, že jim chybí pedagogické a didaktické kompetence. Rokos a Vančura (2020) uvádějí, že si někteří rodiče museli probíranou látku předem nastudovat, protože si ji z dob vlastní školní docházky nepamatovali. Někteří rodiče zápasili s nedostatkem učitelské autority a s motivací dětí ke školní práci (Švaříček et al., 2020).

Z výzkumu mezi českými rodiči vyplynulo, že téměř polovina $(48,2 \%)$ rodičů prvostupňových dětí pomáhala dětem s vypracováváním úkolủ nebo následnou kontrolou cca 2 hodiny denně, ale téměř třetina rodiču $(29,3 \%)$ 3 hodiny a více (Rokos \& Vančura, 2020). Dle Švaříčka et al. (2020) věnovaly škole prvostupňové děti v průměru 3 hodiny denně, přičemž rodiče trávili pomocí dětem 40-60 \% uvedené doby. Vuorikari et al. (2020) zjistili, že se někteří rodiče zapojovali do vzdělávání svých dětí s vlastní iniciativou. Kromě distanční výuky poskytované školou nabízeli dětem doplňkové vzdělávací aktivity. Nani a Sibanda (2020) poukazují na to, že čas strávený s dětmi během vzdělávání doma pomohl rodičům odhalit silné a slabé stránky dětí v učení.

Rodiče byli zásadním prvkem $\mathrm{v}$ zajištění kontinuity vzdělávání dětí a podporou, aby distanční výuka probíhala úspěšně. $V$ této souvislosti je třeba věnovat pozornost zjištění Vuorikari et al. (2020), kdy rodiče vyjadřovali potřebu mnohem větší podpory ze strany školy, konkrétně jak s dětmi zvládat distanční vzdělávání a jak je v náročné pandemické situaci podporovat psychicky.

\section{Rodinný život v době koronavirové pandemie}

Pandemie zasáhla životy rodin $\mathrm{v}$ mnoha aspektech. Rodiče museli trávit s dětmi mnohem více času. Změnily se způsoby vykonávání zaměstnání, zvýšila se pracovní flexibilita. Dopady koronavirové pandemie na hospodářství specificky postihly zejména odvětví s vysokým podílem zaměstnaných žen. Evropský parlament (2021) potvrzuje, že ženy jsou v zaměstnáních, během 
pandemie označovaných jako první linie, zastoupeny v rámci Evropské unie nejpočetněji (např. ve zdravotnictví působí $76 \%$ žen, pokladních je $82 \%$ ).

O’Reilly (2020) neváhá mluvit jako o pracovnicích v přední linii i o ženách, které nesly tíži uzavřených školek a škol. Nejsou zmiňované, nejsou vidět, ale vykonávají základní službu pro celou společnost. Ze strany médií a veřejné politiky měly velmi slabou podporu pro zvládání sociální izolace. Ostře zdůrazňuje, že to byly převážně ženy, komu v době pandemie přibyla odpovědnost za vzdělávání dětí a za udržení funkčnosti izolovaných rodin.

Vzhledem k sociálnímu odstupu nebyla možná sdílená péče o děti. Prarodiče patřili k nejohroženější skupině, nedoporučovalo se, aby svoje vnoučata hlídali (Alon et al., 2020). Wenham (2020) uvádí, že v průběhu pandemie muži převzali část péče o děti a zvýšil se jejich podíl na domácích pracích. Avšak k nárůstu času stráveného těmito činnostmi došlo i u žen. Pod vlivem destabilizujících opatření zůstali doma $v$ některých př́ípadech i partneři. Alan et al. (2020) v tom vidí př́ležitost k narušení stávajících společenských norem legitimizujících nerovnoměrné rozdělení povinností o péči o děti a o domácnost. Řada mužů v této době převzala hlavní roli v zodpovědnosti za péči o dítě.

Extrémní pandemická situace si dle McCrory Calarco et al. (2020a) vybírala svoji daň i na partnerských vztazích. Eskalovaly dlouhodobé zdroje konfliktů, vznikaly i zcela nové, které se týkaly např́klad neshod ohledně závažnosti covidu-19. Rozdílné názory na nebezpečnost pandemie byly pro ženy z jejich výzkumného šetření frustrující, protože to jsou v první řadě ony, kdo má $v$ rodinách na starosti rozhodnutí ohledně zdraví. Tyto konflikty ovlivňují nejen partnerský vztah samotný, ale dopadají i na děti.

V českém prostředí zaznamenali dopad pandemie na duševní zdraví rodičů Korbel a Prokop (2020). V jejich šetření vykazovalo příznaky středně těžké deprese a úzkosti mezi dubnem a listopadem 2020 celkem $27 \%$ rodičů, přičemž příznaky se objevovaly více mezi ženami než mezi muži. K vyššímu nárůstu došlo u rodičů s dětmi na prvním stupni. Především v těchto rodinách docházelo $\mathrm{v}$ průběhu pandemie $\mathrm{k}$ nárůstu počtu konfliktních situací. Výzkumníci se domnívají, že spíš než distanční výuka k vytváření konfliktních situací podněcovala celková situace $\mathrm{v}$ domácnostech.

Rodiče potřebovali v pandemickém čase podporu ze strany politiků i škol. Potřebovali metodickou podporu jak zvládat vzdělávání svých dětí, podporu v prožívání extrémního času, aby nezapomínali na své mentální zdraví a pohodu, protože kvalita jejich prožívání přímo souvisela s kvalitou prožívání jejich dětí - podporu, která podle některých autorů zásadně chyběla. Jak ženy přistupovaly ke vzdělávání doma, jak vnímaly jeho průběh a co potřebovaly, aby pomohly dětem dostát nárokủm distančního vzdělávání, zjišt’uji ve výzkumu kvalitativního charakteru. V následující části přibližuji metodologický postup, definuji cíl a výzkumné otázky. 


\section{Metodologie}

Výzkumným problémem této práce je vzdělávání doma v době koronavirové pandemie. Zaměřuji se na vzdělání doma prvostupňových dětí, jak jej reflektují matky. Cílem výzkumu bylo zjistit, jak matky ke vzdělávání doma přistupovaly, a popsat, s jakými výzvami se potýkaly a jaké strategie volily ke zvládání vzdělávání svých dětí doma.

Využití kvalitativního př́stupu je příslibem tvárného procesu, během kterého „kvalitativní výzkumník nesestavuje ze získaných dat skládanku, jejíž konečný tvar zná, spíše konstruuje obraz, který získává kontury v průběhu sběru a poznávání jeho části““ (Hendl, 2005, s. 52).

V souladu s cílem výzkumu jsem si zúžila výzkumný problém hlavní otázkou, na jejímž základě jsem interpretovala data. Hlavní výzkumná otázka zněla:

HVO: Jak matky přistupují ke vzdělávání doma v době koronavirové pandemie?

Hlavní výzkumnou otázku jsem si v souladu s pyramidovým modelem rozvrstvila do čtyř specifických otázek, jež jsem následně rozvinula do tazatelských (Wengraf, 2001). Pro analýzu dat jsem si definovala následující specifické výzkumné otázky:

SVO1: Jaké vnímají zásahy pandemie do života své rodiny a vzdělávání svých dětí?

SVO2: Jak vnímají vybavenost své rodiny na distanční vzdělávání?

SVO3: Jak vnímají realizaci vzdělávání doma v době pandemie?

SVO4: Jak prožívaly svoji novou roli vzdělavatelky v kontextu svých ostatních rolí?

Při definování specifických výzkumných otázek jsem se se snažila vymezit jasně ohraničený, ale zároveň dostatečně velký prostor pro to, abych dala př́ležitost „vyvstat“ tématům, která respondentky prožívaly jako důležitá.

V rámci svého výzkumu jsem využívala dílčí analytické kroky, které jsou typické pro zakotvenou teorii (grounded theory). „Postupy zakotvené teorie nutí badatele překonat domněnky a vytvořit nový pořádek ze starého. Tvořivost se projevuje schopností badatele vhodně pojmenovat kategorie a také schopností nechat svou mysl volně potulovat a generovat asociace nutné pro tvorbu podnětných otázek a pro objevení rozdílů, které vedou k objevu." (Strauss \& Corbinová, 1999, s. 17)

S ohledem na hlavní výzkumnou otázku bylo základním kritériem výběru respondentek, aby měly alespoň jedno dítě, které je žákem prvního stupně základní školy. Pro větší pestrost vzorku jsem respondentky vybírala tak, aby polovina měla nejvyšší dosažené vzdělání středoškolské s maturitou, polovina dokončené vysokoškolské. Zajímalo mě, zda identifikuji podle úrovně dosaženého vzdělání rozdíly ve vnímání průběhu vzdělávání doma. 
Ve vzorku nejsou zastoupeny společenské extrémy. Prokop (2020) vrství společnost s odkazem na Bourdierovu koncepci tř́ typů kapitálu (ekonomický, sociální a kulturní), aktualizovanou o další specifické formy kapitálu (digitální kompetence) na úzkou společenskou elitu, strádající tř́du a střední trrídu (nejčetněji zastoupenou, bohatě členěnou na dvě vyšší vrstvy a tři vrstvy nižší). Všechny vybrané ženy patří do širokého spektra střední třídy. Stanovená kritéria mi poskytla široké možnosti výběru. Potenciální respondentky jsem oslovila prostřednictvím e-mailu, SMS či aplikace WhatsApp. Výzkumu se zúčastnilo dvanáct respondentek. V tabulce č. 1 uvádím jejich přehled, společně se základními údaji.

Tabulka 1

Charakteristika respondentek.

\begin{tabular}{|c|c|c|c|c|c|}
\hline $\begin{array}{l}\text { Respon- } \\
\text { dentka }\end{array}$ & Věk & $\begin{array}{c}\text { Stupeň } \\
\text { dosaženého } \\
\text { vzdělání }\end{array}$ & Zaměstnání & $\begin{array}{c}\text { Celkový } \\
\text { počet } \\
\text { dětí }\end{array}$ & $\begin{array}{c}\text { Počet dětí } \\
\text { navštěvujících } \\
\text { 1. stupeň }\end{array}$ \\
\hline Alžbeta & 37 & $\begin{array}{l}\text { vysokoškolské } \\
\text { magisterské }\end{array}$ & dramaturgyně & 2 & 1 \\
\hline Barbora & 33 & $\begin{array}{c}\text { středoškolské } \\
\text { s maturitou }\end{array}$ & rodičovská dovolená & 4 & 2 \\
\hline Carla & 39 & $\begin{array}{l}\text { vysokoškolské } \\
\text { magisterské }\end{array}$ & manažerka projektu & 2 & 1 \\
\hline Denisa & 45 & $\begin{array}{c}\text { střední odborné } \\
\text { s maturitou }\end{array}$ & skladová účetní & 2 & 2 \\
\hline Ema & 30 & $\begin{array}{l}\text { střední odborné } \\
\text { s maturitou }\end{array}$ & $\begin{array}{c}\text { rodičovská dovolená } \\
\text { + podnikání }\end{array}$ & 2 & 1 \\
\hline Františka & 38 & $\begin{array}{l}\text { vysokoškolské } \\
\text { magisterské }\end{array}$ & rodičovská dovolená & 4 & 2 \\
\hline Gréta & 39 & $\begin{array}{c}\text { středoškolské } \\
\text { s maturitou }\end{array}$ & referentka kontroly & 2 & 1 \\
\hline Helena & 37 & $\begin{array}{l}\text { vysokoškolské } \\
\text { magisterské }\end{array}$ & $\begin{array}{c}\text { rodičovská dovolená } \\
+ \text { podnikání }\end{array}$ & 3 & 2 \\
\hline Ida & 34 & $\begin{array}{l}\text { středoškolské } \\
\text { s maturitou }\end{array}$ & pracovnice IC & 3 & 1 \\
\hline Julie & 38 & $\begin{array}{l}\text { vysokoškolské } \\
\text { magisterské }\end{array}$ & speciální pedagožka & 4 & 1 \\
\hline Kamila & 38 & $\begin{array}{l}\text { vysokoškolské } \\
\text { bakalářské }\end{array}$ & sociální pracovnice & 2 & 2 \\
\hline Lada & 41 & $\begin{array}{c}\text { středoškolské } \\
\text { s maturitou }\end{array}$ & BTO trenérka & 2 & 1 \\
\hline
\end{tabular}

Jako nástroj sběru dat jsem zvolila hloubkový polostrukturovaný rozhovor. Rozhovory jsem pořizovala přes Microsoft Teams v průběhu listopadu 2020, v době tzv. podzimního lockdownu (druhého uzavření škol). Snažila jsem se 
všechny rozhovory uskutečnit v době uzavření škol kvůli autenticitě prožitku. Přesto byly v několika př́padech rozhovory nahrány v prvních dnech, kdy se žáci prvních a druhých tř́i do škol vrátili. Tato skutečnost i př́islib toho, že je další ročníky budou brzy následovat, se na respondentkách zrcadlily v neskrývané úlevě a optimismu.

Porrídila jsem dvanáct rozhovorů, které v průměru trvaly více než hodinu (nejkratší 53 minut, nejdelší přes 90 minut). Transkripce rozhovorů proběhla v několika kolech, přičemž první přepis přináší pouze hrubou verzi, která je následně doplňována. Někteří výzkumníci poukazují na výhodnost postupu, kdy jeden a ten samý člověk záznam pořizuje, přepisuje a následně analyzuje. Umožňuje mu to „hluboké ponoření se“ do získaných dat (Kowal \& O’Connell, 2014). Přepsané rozhovory jsem zpracovala v softwaru Atlas.ti, při jehož vyvíjení byly do značné míry zohledňovány postupy zakotvené teorie (Hendl, 2005).

V první fázi analýzy dat jsem text „rozložila“ otevřeným kódováním. Kódy jsem pojmenovávala „dvojúrovňově“ (napřx. problémy - třecí plochy). $\mathrm{V}$ průběhu kódování jsem se $\mathrm{k}$ vytvořeným kódům vracela, revidovala je a sledovala četnosti jejich výskytů.

Následně jsem pracovala s axiálním kódováním, jednotlivé kódy jsem seskupila podle významů do „families“. Zároveň jsem si psala poznámky, snažila jsem se najít opakující se vzorce. Families jsem si podle významů dále sdružovala do celků.

Výsledkem jednotlivých analytických kroků je vytvoření celků: průběh vzdělávání doma (digitální vybavenost, problémy, prrínosy a změny), spolupráce rodiny a školy (komunikace, zpětná vazba), př́istup $\mathbf{k}$ učivu (školní práce, rozvíjení učiva, pomůcky), volný čas dětí (volnočasové aktivity, pobyt venku) a žena vzdělavatelka (máma učitelka, role ženy, strategie zvládání), které vedly k vytvoření typologie, která je hlavním výsledkem mé výzkumné práce. $V$ typologii jsem identifikovala pět typů průběhů vzdělávání doma: levou zadní; plníme nad plán; dře to, ale jde to; držíme se zuby nehty a tonoucí se stébla chytá.

\section{Výsledky výzkumného šetření}

Během práce s daty jsem začala objevovat pravidelnosti, které ve výsledku vedly k vytvoření pěti typů př́ístupů žen k průběhu vzdělávání doma. Jednotlivé typy jsou charakterizovány sedmi kategoriemi: organizace školního dne, plnění školní práce, komunikace se školou, přístup matky k učivu, matka v roli učitelky, volný čas dětí a volný čas matky. Kategorie mi umožnily přiřadit respondentky $\mathrm{k}$ jednotlivým typům průběhu vzdělávání doma. Typy a jejich kategorie uvádím v následující tabulce. 


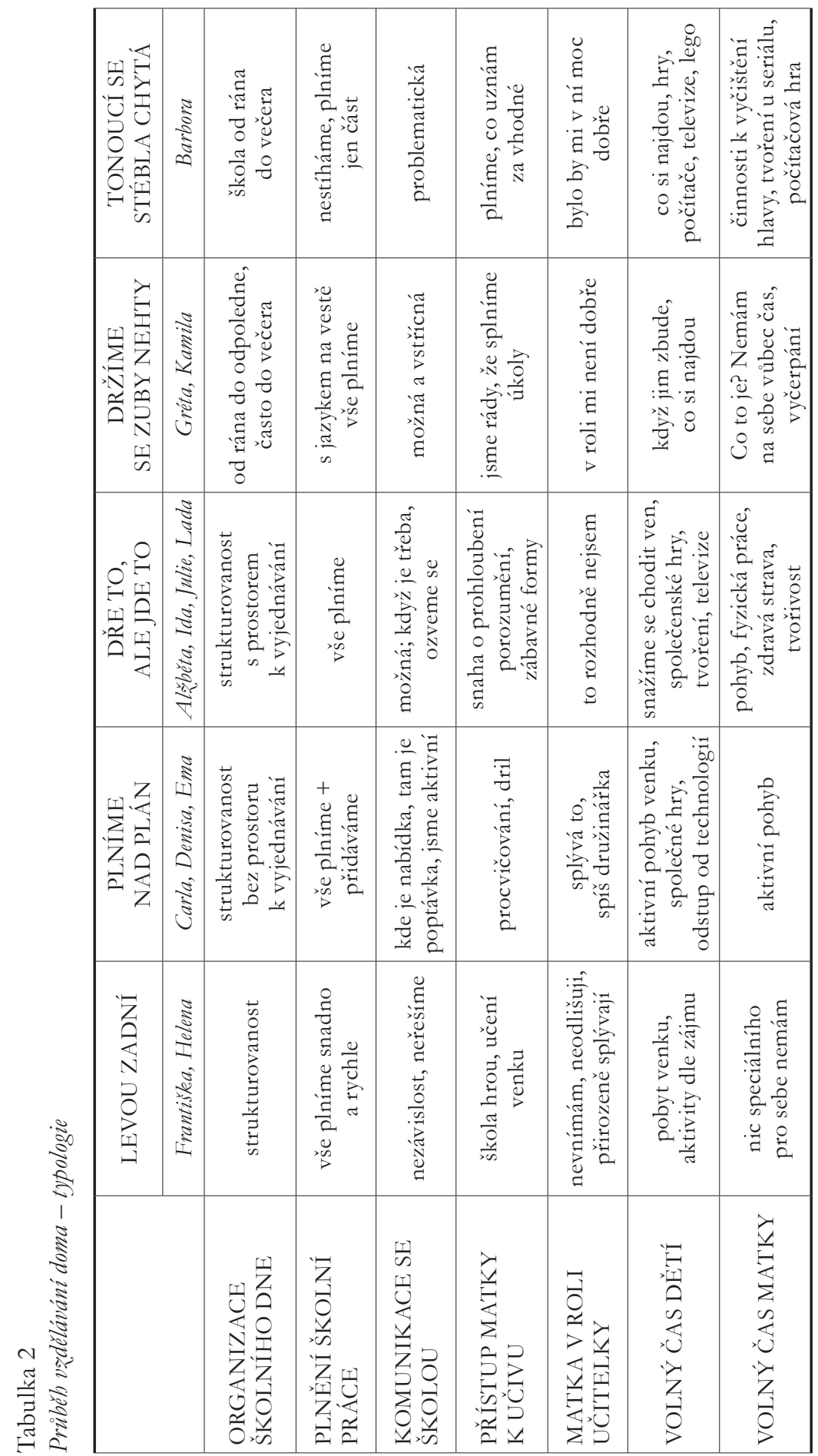


Hlavní vzdělávací povinnost náležela i v době koronavirové pandemie vzdělávacím institucím, přesto značná část učení zůstala na bedrech rodin. $\mathrm{V}$ prrípadě domácností mých respondentek převzaly většinou hlavní zodpovědnost za vzdělávání doma ženy. Argumentovaly tím, že jsou to ony, protože muži chodí do práce. Stejně odpovídaly respondentky na rodičovské dovolené, na ošetřovném, ale i ženy, které vykonávaly svoji práci v rámci home office. Ujišt’ovaly mě, že se mohly na manžely obrátit, pokud by to potřebovaly. Převzetí odpovědnosti vnímaly jako krok ryze praktický. Pokud nechtěly mít školní práci rozloženou do celého dne, bylo pro ně jedinou možností vzdělávání $\mathrm{s}$ dětmi zvládnout během dopoledne a nečekat, až se manžel vrátí z práce.

Některé respondentky delegovaly na své manžely to, co už nestíhaly, nebo učivo, o kterém věděly, že je silnou stránkou jejich manželů. Vyplynulo, že pokud jim možnost zapojit se daly, muži ji využili. Obvykle ve formě vysvětlování učiva.

Další respondentky se své manžely ani nepokoušely do vzdělávání dětí zapojovat. V rozhovorech jsem zaznamenala, že byli jejich manželé z pomoci se vzděláváním „vyřazeni“. Vzdělání dětí měly pevně ve svých rukou respondentky.

Jen v málo př́ipadech se manželé střídali v zodpovědnosti za vzdělávání v rámci stř́dání se na ošetřovném. I v těchto případech však práce, kterou s dětmi splnili, podléhala přísné kontrole manželek.

Respondentky hovořily o tom, že vzdělávání doma na ně př̌šlo i z toho důvodu, že i během běžného chodu školy dělají úkoly s dětmi ony, komunikují se školou.

\section{Levou zadní}

Respondentky prriřazené $\mathrm{k}$ tomuto typu vystihují dvě slova: prrirozenost a svoboda. Vyznačovaly se (v rámci možností) nezávislostí na institucionalizovaném vzdělávání a vysokou angažovaností ve vzdělávání svých dětí. Díky kritičnosti ke školnímu vzdělávání lze předpokládat jasně definovaná očekávání ke škole. Zároveň je tento typ jediný, který reprezentují respondentky se stejnou výší dosaženého vzdělání - vysokoškolskou.

Pro respondentky je charakteristické, že vnímaly školou vyžadovanou práci jako omezující - nemohly čas uzavřených škol plně využít pro to, aby s dětmi pracovaly podle svých představ. Spojuje je přesvědčení o důležitosti vzdělávání vycházejícího z rodiny.

To, co rodina chce, aby dèti umèly, tak se o to prostě musi postarat sama, protože spolébat na školu, si myslim, že neni v tomble to nejlepši. A to neni jediny. Hlavnè ta škola by nemèla bejt jediná pro ty dèti, ta pani učitelka nemuiže být bohyně, která věechno ví. (Helena) 
Školní práci zvládaly děti v krátkém čase během dopoledne. Role matky a učitelky respondentky od sebe neoddělovaly; tím, že má vzdělávání vycházet $z$ rodiny, považovaly je za přirozeně propojené. Učení zařazují do běžných aktivit dne - procházek, společných činností, vaření. Nasazení v učení dětí koresponduje se snahou zajistit svým dětem kvalitně strávený volný čas.

U těchto respondentek vyvstala otázka na domácí vzdělávání. Pro Helenu v době pořizování rozhovoru bylo čerstvou, novou zkušeností. Její nespokojenost s průběhem distanční výuky byla príležitostí $\mathrm{k}$ přechodu do domácího vzdělávání, o kterém již dlouho uvažovala. Nad touto vzdělávací alternativou přemýšlela i Františka, na misce vah však u ní převážil pocit důležitosti vrstevnických kontaktů. I přes její rodičovské výhrady ke školnímu systému jako takovému.

To, そ̌̃e někedy je ta výuka špatná nebo není - ale myslim si, že ješté jsem stále schopná, $i$ když s pani učitelkou v nékterých vécech nesoublasim, to doma néjak obrátit v dobrý,

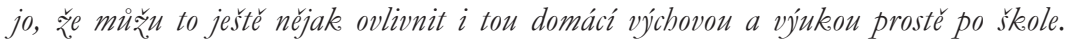

(Františka)

\section{Plnime nad plán}

Pro tento identifikovaný typ zvládání vzdělávání doma je charakteristické, že respondentky měly jeho průběh striktně organizovaný, pevně ve svých rukou. Z jejich výpovědí lze vyčíst motivovanost, smysl pro povinnost. Respondentky vyžadují koncentrovanou školní práci. Včetně online výuky ji děti zvládaly během dopoledne, odpoledne bylo vyhrazené pro volný čas. Své děti podporovaly v samostatném vypracovávání školní práce.

Uzavření škol pojaly jako př́ležitost, aby si děti učivo víc procvičily, zažily. Dle svých slov upřednostňovaly hravou formu - k rozvíjení učiva využívaly sledování dokumentů, čtení knih, hraní společenských a vzdělávacích her. Přesto u tohoto typu nejvíc vystoupilo z rozhovorů procvičování založené na drilování prostřednictvím pracovních listů a cvičení v učebnicích.

Denisa svým dětem přidávala práci tím, že musely vypracovávat cvičení celá, přestože v zadání bylo, že pokud látka dětem půjde, stačí, aby vypracovaly pouze pár př́ikladů. Argumentovala, že některé znalosti se naučí pouze drilem, navíc ji u dětí rozčiluje úroveň znalostí pravopisu:

Když vidím, jak v současný době dèti pišsou, mluví... a dèti ted’ podle mè třeba málo čtou.

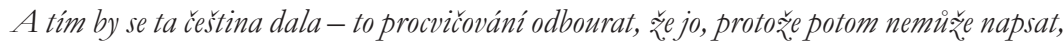
já nevím, seskupeni s tvrdým y, ale protože to je do prírodovédy, tak to je jedno. Toble jsou

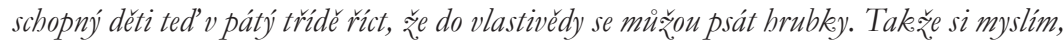
že to, že to proto clovéke pridává, proto že ví, že nikde jinde ty dèti se ke tomu dalšimu procvičování nedostanou. (Denisa) 
Respondentky nechtěly být označovány jako učitelky svých dětí, neměly pocit, že by se v takové roli ocitly. Denisa se zamýšlela, že její roli ve vzdělávání dětí spíš vystihuje družinářka. Díky vzdělávání doma lépe poznaly možnosti i limity svých dětí.

Když máš ditě doma, take mữ̌eš posunovat branice. Jako ože toble je zadaný od pani učitelky pro ten pruimèr, ted' to nechci, aby to neznělo bloupé, jejda, a ted' ty to más hotový za puil

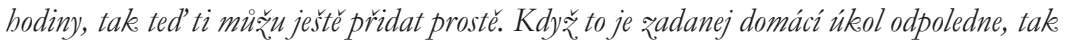

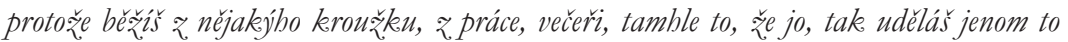
nezbytně nutný, zbytek u气̌prèce dèlali ve škole. (Carla)

\section{Dre to, ale jde to}

Čas pro školní práci měly respondentky pevně strukturovaný, poskytly však svým dětem prostor k vyjednávání. Úkoly děti plnily bez problémů, odevzdávaly je včas, práci navíc svým dětem záměrně nepřidávaly. Zdůrazňovaly, že rozhodně nebyly učitelkami svých dětí, necítily se v roli dobře. „Dřeni““ v názvu poukazuje na to, že tyto respondentky zápasily, jak samy vypovídaly, s absencí učitelské autority. Alžběta se v nové roli cítila velmi nepř́ijemně. Vnímala, že stejně to prožívá i syn, který jí neustále opakoval, že není jeho učitelka. Někdy musela Alžběta předkládat synovi důkazy, aby ho ke školní práci přesvědčila.

Já mu to samožrejmé i rúkáam, ano, já nejsem pani učitelka, ale prostě ted’ holt to musime zvládnout spolu, tak to zuládnem nèjak, a protože já jsem tady ta starši a vim, jak to más dèlat, take to prosté budeme dèlat podle mè. Ale nemrzí mè to, ne, to já zase naprosto chápu, že on to tak má. Mrrí mé to, že si jenom ríkám, jestli to teda fakt nedèlám blbě... pořád mi bude ríkat, že nejsem pani ucitelka, že pani učitelka to vysvètluje lip a že nemám pravdu, protože pani učitelka nic takovýho neřekla, teprve až kdy ž mu ukážn v mailu, že pani učitelka mi piše, že má toble udělat, tak rekene no tak dobrè. (Alžběta)

Pokud respondentky viděly, že jsou děti unavené a nesoustředěné, raději školní práci přerušily a vrátily se $\mathrm{k}$ ní jindy. Množství učiva považovaly za adekvátní. Svoji pozornost soustředily na to, aby s dětmi procvičovaly učivo, které jim dělalo problémy. Usilovaly o rozvíjení porozumění. Aktivity, kterým dětem učení zpestřovaly, je napadaly z hlavy. Na brouzdání po internetu, hledání jiných pomůcek a nápadů, co s dětmi dělat, neměly kapacitu. Pro respondentky tohoto typu je charakteristické, že si byly vědomy svých možností. I když věděly, že by mohly pracovat s dětmi jinak, nenechaly se tím pohltit a uštvat, jak popisuje Julie.

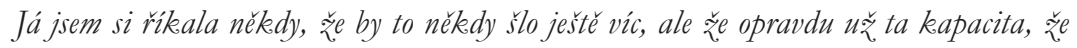
tréba vènovat se ještě tèm mladšm sourozencium, že nèjak u气̌ to nešlo, a asi v ten moment jsem byla take někdy, já nevím, unavená nebo vyštavèná psychicky, že už mè to asi bylo i možná jedno v ten moment, kdy ž to takble vezmu. (Julie) 


\section{Držime se zuby nehty}

Respondentkám z tohoto identifikovaného typu se nedařilo vymezit čas pro plnění školní práce. Pravidelně jim zasahovala do odpoledne, nebylo výjimkou, že děti odesílaly poslední úkoly večer. Děti ale všechny své školní povinnosti zvládaly a odevzdávaly. Pro respondentky je charakteristické, že prožívaly dobu uzavřených škol jako velmi náročnou, hektickou. Byly uštvané.

Za upozornění stojí zajímavý paradox - tyto respondentky popisovaly, že na sobě vnímaly příliš mnoho nároků a všem se snažily dostát, což vedlo k jejich vyčerpání. Zároveň však Kamila měla od školy svých dětí podporu, jakou můžeme označit za př́klad dobré praxe. Škola byla s rodiči neustále v kontaktu, povzbuzovala je, rodiče za jejich pomoc oceňovala, uspořádala jim i online seminář o specificích školní práce s prvostupňovými dětmi. Ačkoliv by bylo možné očekávat s vyššími ročníky vyšší míru samostatnosti, Gréta do všech aktivit své dcery, žákyně páté třídy, zasahovala. O školní práci nemluví jako o práci dcery, ale o jejich společné. Správnost svého počínání si potvrzuje výroky kolegyň z práce.

Když mě vidi, jak to proživám, ty telefonáty a to v̌̌echno, tak zase slýchám od nich, že dcera mị்̌ být ráda, ře má takovýho rodiče, kterej se snaží, aby tu školu nezanedbala, že jsme asi jedni z. mála, keterí se tak vènujou ditéti, tak aby to tu školu nèjak zuládlo. Že nezávidí tèm dètem, kterri rodiče si toho nevšimaj a nechaj je v tom. (Gréta)

Respondentky neřešily metodiku vzdělávání doma. Díky posílaným úkolům se pro ně učení smrsklo, slovy Kamily, na otrocké vyplňování. Obě respondentky se cítily v roli učitelky nepř́ijemně. Čas podzimního uzavření škol nesly těžce. Otevřeně mluvily o tom, že podzimní situaci nezvládaly, byly vyčerpané. Kamila jela celý ř́jen a listopad podle svých slov na spánkový a osobní dluh vưči sobě sama, plnila mechanicky to, co přicházelo. Což nešlo do nekonečna.

Prišla jsem z.práce, chtéla jsem jit s dètma ven, chtèli jsme jît hrabat listí. Ale ríkala jsem si, já potřebuju ještě tady néco dodělat do práce, jenom si na chvilku otevru ten počítač, a já jsem tam sedèla do puil sedmé, a pak najednou koukám venku tma, dècka nevyvenčený, a já jsem z. toho byla tak. neštastná, no tak, jsem v sobotu ráno vstala, brě́ela jsem, $v$ nedèli jsem brě́ela, por̀ád jsem brečela, já jsem si ríkala toble neni možný, takble já žit jako nemůz̆u. (Kamila)

Zajistila si však odbornou podporu prostřednictvím supervize, kde si ujasnila priority, jichž se snaží držet. Gréta začala postupně v tlaku na dceru povolovat, zjistila, že křik k ničemu nevede. 


\section{Tonouci se stébla chytá}

Ačkoliv metodologická literatura varovně zdvihá prst ve chvíli, kdy se objeví v kategorii jediný př́ípad (Šed’ová \& Švaříček, 2013), po zvážení jsem se rozhodla ke kategorii „Tonoucí se stébla chytá“ přiřadit průběh vzdělávání doma $\mathrm{v}$ rodině Barbory. To, že se $\mathrm{v}$ této kategorii ocitla sama, koresponduje s tím, že i ve své snaze zvládnout vzdělávání doma byla solitérem. Dostalo se jí malé podpory ze strany rodiny, za alarmující považuji, že i podporu ze strany školy prožívala jako nedostatečnou. Její osamocenost v tomto typu je dána i tím, že je jedinou respondentkou, které se nepodařilo dostát všem nárokům, které na děti škola kladla. Na plnění některých povinností v rámci distanční výuky rezignovala.

Respondentka nenastavila strukturovaný čas pro školní práci, děti ji měly rozloženou do celého dne. Měla pocit, že se na ni ze školy neustále valí úkoly. Zadání úkolů se jí v různých komunikačních kanálech, které škola používala, nedařilo zachytit, takže děti neodevzdávaly všechnu požadovanou práci.

Vlastnè jsem premýslela nad tím, že jediný, co já dělám, taǩže jen plnim úkoly. Takžze já se snima neučm, jediný co, tak plnime úkoly. Cožje strašně na prd. Proto ̌̌e nemám ani ten čas, že máme tolik úkolư, že nemám ani čas se zastavit a trošku s nèma nèco probrat. (Barbora)

Komunikace se školou byla problematická. Když nezvládala školní práci se synem, bylo jí řečeno, že ostatní děti tu samou práci zvládají. Dcera vypadla z výuky angličtiny. Malotřídní škole se nepodařilo zajistit plnění individuálního plánu, který pro tento předmět její dcera má. Učitelka se s Barborou sice snažila komunikovat, té se však přesto nepodařilo maily se zadáním práce dohledat, až se nakonec rozhodla angličtinu neřešit.

Barbora tvrdila, že by byla vůči svým dětem ráda v roli učitelky. Ráda by dětem vysvětlovala učivo, chystala úkoly a pomáhala s jejich vypracováváním. Domnívala se, že podzimní uspořádání distanční výuky jí k tomu nedalo př́ležitost. Požadovala větší nezávislost na škole.

V rozhovoru s respondentkou jsem si všimla dvou rozporů. Přestože si stěžuje na nedostatek času, přidělávala si práci tím, že dělala za děti některé úkoly do výtvarné výchovy (protože ji to bavilo) nebo psala úlohy za syna (aby mu ulehčila). Hovořila o tom, že jsou děti z online výuky velmi unavené. Podstatnou náplní jejich volného času ale bylo hraní počítačových her a sledování televize. Respondentka si uvědomovala, že potřebuje čas jen pro sebe, činnost, u které může vypnout. K vyčištění hlavy jí nejvíc jejími slovy pomáhá večerní seriál nebo počítačová hra.

Hraju Minecraft, sem tam, kdy žpotřebuju faket vypnout a když užjsem faket rožçilená a mám strach, že ty dèti pozabijim, tak si zahraju chvilku Minecraft, dvě tri hodiny... Někedy jsem schopná si hrát tréba do těch trú hodin do rána. Do trú hodin do rána jsem si jednou tak hrála, protože jsem si ríkala, já ư̌jsem z toho tak nešttastná. (Barbora) 


\section{Diskuze a závěr}

Dvanáct respondentek, dvanáct různých pohledů na průběh vzdělávání doma. V podobných podmínkách je prožívaly velmi odlišně. Data získaná z rozhovorů vykrystalizovala do typologie pěti prúistupů matek ke vzdělávání doma. Klíčovými kategoriemi pro zařazení respondentek k jednotlivým typům byly organizace a plnění školní práce, př́istup matek k učivu a jak se cítily v roli učitelky. Kromě typu „tonoucí se stébla chytác se dařilo matkám zajistit, aby děti plnily a odevzdávaly veškerou zadanou školní práci. Pro zvládání vzdělávání doma pojmenovávala většina matek jako důležitou komunikaci se školou. Dokonce komunikace nemusela přímo probíhat, respondentkám stačilo, pokud věděly, že je možná. Respondentky přiřazené k typům „plníme nad plán“, „dře to, ale jde to“ a „držíme se zuby nehty“ se v rámci vzdělávání doma nepovažovaly za učitelky svých dětí, popřípadě jim v této roli nebylo dobře. Za pozornost stojí podobnosti u extrémních pólů typologie: „levou zadní“ a „tonoucí se stébla chytá“ spojuje nezávislost na škole. U př́stupu „levou zadní “ cílená, záměrná a matkami zvolená, u přístupu „tonoucí se stébla chytá“" však vyplývající z problematické komunikace.

Ze získaných dat vyplývá, že je třeba detekovat, jak rodiče vzdělávání doma zvládají a podle toho jim poskytovat cílenou podporu. U všech respondentek je patrná snaha zapojit se do vzdělávání doma, avšak s rozdílnými výsledky. V některých rodinách vedla ke spokojenému společnému prožívání nezvyklého pandemického času, $\mathrm{v}$ dalších rodinách vedla $\mathrm{k}$ třecím plochám a některé respondentky se jí téměř nechaly uštvat.

Koronavirová pandemie uzavřela rodiče a jejich děti do domácností, které se kvůli tomu proměnily ve školy, školky, volnočasové kluby a dětská hřiště. $V$ některých př́ipadech i pracoviště rodičủ. Většina respondentek prožívala čas jako náročný, kdy se ve vlnách střídaly lepší dny s horšími. Některé s náznakem lehkého provinění naopak hovořily o tom, že to pro ně byl klidný, svobodný čas, který si velmi užívaly. Většina respondentek byla za čas, kdy mohly být víc se svými dětmi, ráda, i když přiznávaly, že to bylo někdy velmi náročné. Výše zmíněné respondentky neprožívaly to, co popisují Korbel a Prokop (2020) ve své studii, kdy 27 \% jejich respondentů vykazovalo znaky středně těžké deprese. V mém výzkumu se však objevilo i několik respondentek, které prožívaly čas jako velmi náročný, což vedlo $\mathrm{v}$ př́padě jedné $\mathrm{z}$ nich $\mathrm{k}$ úplnému fyzickému a psychickému vyčerpání.

McCrory Calarco et al. (2020a) hovoří o eskalaci dlouhodobých zdrojů konfliktů v partnerských vztazích. Nárůst konfliktních situací, související s celkovými nároky pandemické doby, zúčastněné respondentky také reflektovaly. Za pozitivní zjišstění považuji, že respondentkám v naprosté většině případů tato zkušenost potvrdila, že se na sebe s manželem mohou spolehnout, popisovaly vliv pandemické zkušenosti na jejich partnerské vztahy jako posilující. 
Zvýšené množství času a péče, které bylo potřeba věnovat dětem, dopadlo častěji, jak upozorňují McCrory Calarco et al. (2020b), O’ Reilly (2020) a Wenham (2020), na ženy. To potvrzují i respondentky z mého výzkumu. Bez ohledu na to, zda byly doma na rodičovské dovolené s mladšími dětmi, pracovaly z domova formou home office anebo chodily do práce, hlavní zodpovědnost za vzdělávání nesly ony. Otázka na hlavní zodpovědnost za vzdělávání $\mathrm{v}$ ženách spolehlivě vyvolala smích a pobavení. $Z$ výpovědí lze usuzovat, že to kopíruje běžný stav v jejich domácnostech, kdy vypracovávání úkolů s dětmi, komunikace se školou a organizace volnočasových aktivit spadá pod „agendu“ matek.

Pro distanční online vzdělávání byly jejich domácnosti digitálně vybavené dostatečně, pouze jedna respondentka si půjčovala notebook ve škole, jinak rodiny všechna potřebná zařízení doma měly. Do té doby většinou respondentky své děti v ovládání digitálních technologí́ nepodporovaly. Digitální kompetence, jak je zmiňují Nani a Sibanda (2020), pro ženy problém nebyly. Zároveň nehodnotily, že by se $\mathrm{v}$ nich během distanční výuky dětí zlepšily, pouze se naučily pracovat s nástroji online konferencí.

Korbel a Prokop (2020) dokládají, že od prvního uzavření škol na jaře 2020 do druhého podzimního uzavření škol 2020 došlo k výraznému zlepšení digitálních kompetencí dětí, což také přispělo $\mathrm{k}$ tomu, že mohla na podzim 2020 probíhat distanční výuka strukturovaněji, s větší oporou o online výuku. Výsledky mého výzkumného šetření přináší jiný poznatek. Respondentky tvrdily, že během těchto uzavření nedošlo $\mathrm{k}$ výraznému rozvoji digitálních kompetencí, zejména u mladších dětí. Během online výuky využívaly pouze zapínání a vypínání mikrofonu a hlášení se. Vnímaly ale, že se děti před počítačem víc osmělily. U dětí z pátých ročníků respondentky vyjadřovaly rozladění, že ačkoliv měly děti jeden rok výuky informatiky, nebyly školou na online vzdělávání připravené.

Respondentky se shodly na tom, že distanční výuka probíhala na podzim 2020 strukturovaněji. Zatím co Nani a Sibanda (2020) popisují, že rodiče vnímali distanční výuku jako něco, co pomohlo nastolit v jejich rodinách disciplínu a řád, některé respondentky tohoto výzkumu popisovaly online distanční výuku jako komplikaci, která výrazně zasahovala do chodu domácnosti a které se museli podřizovat zbývající členové rodiny. Podzimní pevná struktura pro ně byla svazující, v prŕípadě více dětí, které měly online výuku, i komplikovaná na organizaci - kvůli zajištění prrístrojů či klidu na soustředěnou práci.

Celkově však hodnotily online distanční výuku jako př́nosnou. Školy na sebe převzaly zpět zodpovědnost za výklad a procvičování učiva.

Respondentky přistupovaly k vzdělávání doma s různou mírou iniciativy, stejně jako popisují Vuorikari et al. (2020). Některé respondentky byly rády, že děti zvládly úkoly splnit a odevzdat. Další respondentky se snažily učivo 
předávat dětem hravou formou, hledaly jiné metody, pracovaly s knihami, nabízely dětem sledování dokumentů, využívaly edukační potenciál společenských her. Část mých respondentek řešila otázky správného metodického postupu a didaktických dovedností, což koresponduje se zjištěním Švaříčka et al. (2020). Problematika nedostatku učitelské autority byla také pro některé respondentky důležitým tématem, což se promítalo do popisů „soubojü“ s dětmi, které odmítaly pracovat podle matek, protože „paní učitelka to ř́ká jinak".

Napříč všemi kategoriemi ženy hovořily o tom, že jim vzdělávání doma umožnilo víc nahlédnout do učení jejich dětí, v čemž se shodují s výsledky výzkumu Nani a Sibanda (2020). Identifikovaly jejich silné stránky, začaly si všímat limitů. Objevily oblasti, ve kterých do budoucna očekávají problémy. Některé tato zkušenost dovedla $\mathrm{k}$ tomu, že se chtějí víc zajímat o to, co a proč se děti učí či chtějí být aktivnější v komunikaci směrem ke škole. Byla vyslovena očekávání, aby zkušenost s distančním vzděláváním v době pandemie vedla ke změnám ve školním systému.

Při výběru vzorku jsem stanovila jako jednu z kategorií stupeň dosaženého vzdělání. Zajímalo mě, zda se v datech prokáže jeho dopad na zvládání vzdělávání doma. Respondentky, zařazené do kategorie „levou zadní“, charakteristické rychlým zvládáním školních požadavků, byly obě s vysokoškolským vzděláním. V dalších třech kategoriích, charakteristických úspěšným plněním školní práce s různou strukturovaností a délkou školní práce, byly respondentky s vysokoškolským i stř̌edoškolským vzděláním zastoupeny rovnoměrně. V kategorii „tonoucí se stébla chytáa byla výše dosaženého vzdělání respondentky středoškolská. Můžeme se domnívat, že by ženy podobných charakteristik vykazovaly obdobné př́istupy ke vzdělávání svých dětí doma. Téma souvislosti dosaženého vzdělání matek a průběhu vzdělávání dětí doma v době pandemie by mohlo být uchopeno dalšími výzkumy.

Lze předpokládat, že dopadům pandemie na vzdělávání bude věnováno mnoho pozornosti ze strany výzkumníkủ, politiků či mezinárodních organizací. Přinesla výzvy, které budou muset být řešeny. Bude však dostatek pozornosti věnován i rodinám, které se dlouhodobě snažily vytvořit svým dětem bezpečné místo $\mathrm{v}$ nejistém světě pandemie a podporovaly je ve vzdělávání? McCrory Calarco et al. (2020b) apelují, že je veřejným zájmem sledovat a zkoumat, jak tento intenzivní čas s dětmi doma působí na emoční pohodu matek. Zvýšené prožívání stresu, úzkosti a frustrace, které jejich respondentky vykazovaly, může mít dopad nejen na mentální zdraví žen, ovlivňuje i zdraví, chování a školní úspěšnost dětí. Podobná zkoumání mohou přinášet podklady pro vytvoření strategií, jak podporovat rodiny v těžkých časech. 


\section{Literatura}

Alon, T., Doepke, M., Olmstead-Rumsey, J., \& Tertilt, M. (2020). The impact of COVID-19 on gender equality (No. 26947). National Bureau of Economic Research. https://doi.org/10.3386/ w26947

Carretero, S., Napierała, J., Bessios, A., Mägi E., Pugacewicz, A., Ranieri, M., Triquet, K., Lombaerts, K., Robledo-Bottcher, N., Montanari, M., \& Gonzalez-Vazquez, I. (2021). What did we learn from schooling practices during the COVID-19 lockdown. Insights from five EU countries. Joint Research Centre (EC). http://doi.org/10.2760/135208

Člověk v tísni. (2021, 31. ledna). Vice nežcucturtina dètí nerozumi probírané látce. Šetréní ukázalo, jak se uči na dálku sociálnè znevýhodnèné dèti. https://www.clovekvtisni.cz/jak-se-uci-na-dalkusocialne-znevyhodnene-deti-7374gp

Di Pietro, G., Biagi, F., Costa, P., Karpiński, Z., \& Mazza, J. (2020). The likely impact of COVID-19 on education: Reflections based on the existing literature and recent international datasets. Joint Research Centre (EC). http://doi.org/10.2760/126686

European Parliament. (2021, 1. března). Understanding Covid-19's impact on women. https://www. europarl.europa.eu/news/en/headlines/society/20210225STO98702/understanding-theimpact-of-covid-19-on-women-infographics

Frombergerová, A. (2020). Distanční vzdělávání v době pandemie pohledem čtyř účastníků vzdělávacího procesu. Pedagogická orientace, 30(2), 221-230. https://doi.org/10.5817/ PedOr2020-2-221

Hendl, J. (2005). Kvalitativni výzkum. Základni metody a aplikace. Portál.

Korbel, V., \& Prokop, D. (2020). Distančni výuka na jaře a na podżim. Výsledky reprezentativníbo kvantitativníbo výzkumu 2020. PAQ Research. https://drive.google.com/file/d/ 1k4QZVuyCy0U-WlZvaCE1JsMj7LqxjP6d/view

Kowal, S., \& O'Connell, D. C. (2014). Transcription as a crucial step of data analysis. In U. Flick (Ed.), The Sage handbook of qualitative data analysis (s. 64-78). SAGE.

Lucas, M., Nelson, J., \& Sims, D. (2020). Schools' responses to Covid-19: Pupil engagement in remote learning. NFER. https://www.nfer.ac.uk/media/4073/schools_responses_to_covid_19_ pupil_engagement_in_remote_learning.pdf

McCrory Calarco, J., Meanwell, E., Anderson, E., \& Knopf, A. (2020a). „My busband thinks I'm crazy": COVID-19 related conflict in couples with young childrem. http://doi.org/10.31235/osf. io/cpkj6

McCrory Calarco, J., Meanwell, E., Anderson, E., \& Knopf, A. (2020b). „Let's not pretend it's fun: How COVID-19 related school and childcare closures are damaging mother's well-being. http:// doi.org/ 10.31235/osf.io/jyvk4

Ministerstvo školství, mládeže a tělovýchovy. (2020). Metodické doporučení pro vždělávání distančnim zpiósobem. https://www.edu.cz/wp-content/uploads/2020/09/metodika_ DZV__23_09_final.pdf

Nani, G. V., \& Sibanda, L. (2020). Online home schooling: Are parents ready? Lessons from the corona virus disease induced lock down. Randwick International of Education and Linguistics Science Journal, 1(2), 140-151. https://doi.org/10.47175/rielsj.v1i2.81

O’Reilly, A. (2020). „Trying to function in the unfunctionable“: Mothers and COVID-19. Journal of the Motherhood Initiative, 11(1), 7-24. https://jarm.journals.yorku.ca/index.php/ jarm/article/view/40588/36759

Pavlas, T., Zatloukal, T., Andrys, O., \& Neumajer, O. (2021). Distanční vąélávánív qákladnich a strédnich škelách. Př́stupy, posuny a zkušenosti škol rok od nástupu pandemie nemoci covid-19. 
Tematická zpáva České škeolní inspekce. https://www.csicr.cz/Csicr/media/Prilohy/2021_p\%_C5\% 99\%C3\%ADlohy/Dokumenty/TZ_Distancni-vzdelavani-v-ZS-a-SS_brezen-2021.pdf

Prokop, D. (2020). Slepé skevrny. Host.

Rokos, L., \& Vančura, M. (2020). Distanční výuka při opatřeních spojených s koronavirovou pandemií - pohled očima učitelů, žáků a jejich rodičů. Pedagogická orientace, 30(2), 122-155. https://doi.org/10.5817/PedOr2020-2-122

Strauss, A., \& Corbinová, J. (1999). Základy kvalitativníbo výzkumu. Postupy a techniky metody zakotvené teorie. Albert.

Šed’ová, K., \& Švaříček, R. (2013). Jak psát kvalitativně orientované výzkumné studie. Kvalita v kvalitativním výzkumu. Pedagogická orientace, 23(4), 478-510. http://dx.doi.org/10.5817/ PedOr2013-4-478

Švaříček, R., Straková, J., Brom, C., Greger, D., Hannemann, T., \& Lukavský, J. (2020). Spolupráce rodiny a školy v době uzavřených základních škol. Studia paedagogica, 25(3), 9-41. https://doi.org/10.5817/SP2020-3-1

UNESCO. (2020). Supporting families and children beyond COVID-19. https://www.unicef-irc. org/publications/1165-supporting-families-and-children-beyond-covid-19-socialprotection-in-high-income-countries.html

UNESCO. (2021). COVID-19 and school closures. One year of education disruption. https://data. unicef.org/resources/one-year-of-covid-19-and-school-closures/

United Nations. (2020, 15. dubna). Policy brief: The impact od COVID-19 on children. https:// unsdg.un.org/resources/policy-brief-impact-covid-19-children

Vuorikari, R., Velicu, A., Chaudron, S., Cachia, R., \& Di Gioia, R. (2020). How families handled emergency remote schooling during the Covid-19 lockdown in spring 2020. Joint Research Centre (EC). https://doi.org./doi:10.2760/31977

Wengraf, T. (2001). Qualitative research interviewing: Biographic, narrative and semistructured methods. SAGE.

Wenham, C. (2020). The gendered impact of the COVID-19 crisis and post crisis period. European parliament. https://www.europarl.europa.eu/RegData/etudes/STUD/2020/658227/ IPOL_STU(2020)658227_EN.pdf

World health organization. (2020, 12. března). Director-General's opening remarks at the Mission briefing on COVID-19-12 March 2020. https://www.who.int/dg/speeches/detail/whodirector-general-s-opening-remarks-at-the-mission-briefing-on-covid-19---12-march-2020.

Zákon č. 349/2020 Sb., zákon, kterým se mèni zákon č. 561/2004 Sb., o prédškolnim, základnim, střednim,

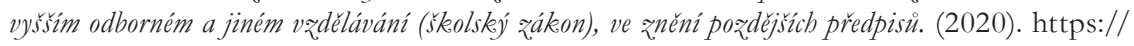
www.zakonyprolidi.cz/cs/2020-349

\section{Kontakt na autora}

Daniela Šimková

Ústav pedagogických věd, Filozofická fakulta, Masarykova univerzita

E-mail: 182012@mail.muni.cz

\section{Corresponding author}

Daniela Šimková

Department of Educational Sciences, Faculty of Arts, Masaryk University

E-mail:182012@mail.muni.cz 
